\title{
ROMANIA, THE CSCE AND THE LEGACY OF WORLD WAR II
}

\section{Rumanía, el CSCE y el legado de la Segunda Guerra Mundial}

\author{
CEZAR STANCIU \\ University Valahia of Târgoviște \\ cezar.stanciu@valahia.ro
}

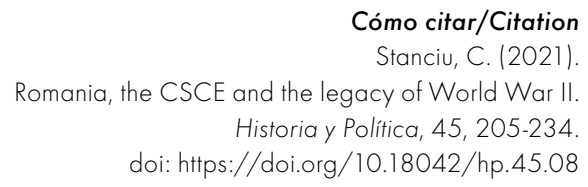

(Reception: 29/02/2020; review: 05/06/2020; acceptance: 17/07/2020; publication: 01/06/2021)

\begin{abstract}
The CSCE process was regarded by the Soviet Union as an opportunity to settle unresolved issues of the Second World War such as the recognition of its Western borders as victorious power. Romania too saw the conference as an opportunity but in another sense: to put an end to a world of victors and losers replacing it with the equality of all states. Moscow's status as victor was the source of its hegemony in Eastern Europe, as the regime in Bucharest understood it, which is why challenging the relations and bipolarity originating from the war was Romania's primary aim. As the regime in Bucharest claimed to pursue an independent course towards Communism and refused subordination to Moscow, Romania had reasons to presume that its security was threatened by the Soviet Union. This article
\end{abstract}


explores Romania's approach to the CSCE, the ideas it advanced and the rhetoric it used trying to undermine the bipolarity and hegemony which placed the country in the Soviet sphere of influence and explained the Brezhnev doctrine. Undermining the principles which offered Moscow such power and also promoting instruments (both legal and institutional) to limit superpower domination, Romania hoped to secure its independence and gain protection against the Soviets.

\section{Keywords} War.

CSCE; Romania; Soviet Union; bipolarity; hegemony; Western Europe; Cold Resumen

La Unión Soviética consideró el proceso de la CSCE una oportunidad para resolver problemas que pendientes tras la Segunda Guerra Mundial; por ejemplo, el reconocimiento de sus fronteras occidentales como potencia victoriosa. Rumania también vio la conferencia como una oportunidad, pero en otro sentido: el de poner fin a un mundo de vencedores y perdedores, reemplazándolo por la igualdad de todos los Estados. El régimen de Bucarest entendía que el estatus de Moscú como vencedor era la fuente de su hegemonía en Europa del Este y por eso su objetivo principal fue desafiar las relaciones y la bipolaridad originadas en la guerra. Debido a su intento de seguir su propia vía hacia el comunismo y no subordinarse a Moscú, Rumania tenía razones para creer que su seguridad estaba amenazada por la Unión Soviética. Este artículo explora el enfoque rumano de la CSCE: las ideas que propuso y la retórica que utilizó para tratar de socavar la bipolaridad y la hegemonía que colocó al país en la esfera de influencia soviética y explicó la doctrina Brezhnev. Rumanía esperaba asegurar su independencia y obtener protección frente a los soviéticos minando los principios de los que procedía el poder de Moscú y promoviendo instrumentos (tanto legales como institucionales) para limitar el dominio de las superpotencias.

\section{Palabras clave}

CSCE; Rumania; Unión Soviética; bipolaridad; hegemonía; Europa Occidental; Guerra Fría. 


\section{CONTENTS}

I. THE MULTIPLE MEANINGS OF INTERNATIONAL DETENTE. II. THE SPIRIT OF POTSDAM. III. ROMANIAN-WEST EUROPEAN RELATIONS IN THE CONTEXT OF THE CSCE. IV. CONCLUSION. BIBLIOGRAPHY. ACRONYM.

At the time the Conference on Security and Co-operation in Europe (CSCE) process was initiated, the Romania were already well-known for its long-standing opposition to Soviet control. Bearing in mind Nicolae Ceaușescu's fierce condemnation of the Soviet-led intervention in Czechoslovakia, it was certainly predictable that Romania was going to fight off the Brezhnev doctrine through any means possible in the context of the largest postwar conference in Europe ${ }^{1}$. Romania did set a very ambitious agenda for its participation in Helsinki, but along the difficult path to the conference, the Romanian leaders lost more than what they gained. Still, the CSCE facilitated a transformation in the international identity of the Communist elites in Bucharest which serves to further demonstrate the erosion of the Soviet bloc and the degradation of Communist internationalism.

When the Romanian party leadership first opposed the Soviets, in the early 1960s, their argumentation was conceived in Marxist-Leninist terms, drawing from the Titoist rhetoric on national Communism and perhaps on the Italian theses on the autonomy and polycentrism of Communist parties ${ }^{2}$. It was, in other words, a feud inside international Communism in which the Romanian Communists took advantage of the emerging Sino-Soviet polemic in order to assert their right to an independent course ${ }^{3}$. The bone of contention was the Romanian leaders' perception that the Soviets opposed their plans to accelerate a Stalinist version of heavy industrialization ${ }^{4}$. As divergences deepened, the Romanian political elites elaborated new narratives on their power accession which decreased the role of the Soviet factor and turned the consequences of World War II into a taboo.

But a major yet under investigated event which shaped Romania's policies vis-a-vis the Soviet Union was the Soviet-American detente of 1972. As

\footnotetext{
Bloed (1993)

Tismăneanu (2003): 178-179.

3 Radchenko (2009): 98-102.

4 Deletant (2008): 91.
} 
Elena Dragomir wrote recently, the Romanian leaders perceived detente as a threat to their independence since it appeared to consolidate the bipolar organization of the postwar world. Based on such a view, the Romanian elites saw the CSCE both as a risk, in the sense of confirming the bipolar character of detente, but also as an opportunity to fight off the hegemony of the superpowers 5 . In this context, the Romanian discourse underwent significant transformations in comparison with the ideological argumentation used before - in the famous Declaration of 1964, for example, when it claimed each party's right to build Communism according to national specificities.

This study evaluates the impact of detente on Romania's position at the CSCE, the key directions of Romania's participation at the conference and the argumentation it used. Since the conference may be considered a substitute for the peace conference which never followed World War II, the CSCE was regarded by the Romanian Communist leadership as an opportunity to claim the redundancy and dismissal of the postwar arrangements which placed Romania under Soviet control. Bipolarity, enforced either by conflict or by cooperation, was regarded as the source of hegemony and the opposite of detente. The CSCE, N. Ceaușescu's regime hoped, was going to challenge the postwar political organization of Europe and reshape relations on the Old Continent according to new principles, in the spirit of what was later called a multilateralization of detente ${ }^{6}$.

The methodological approach of this article relies on reinterpreting the political decision-making process in a double perspective, both perceptual and institutional. Drawing on unpublished archival material, the article explains how Romanian decision-makers perceived their options, how their interpreted the international environment but also how the institutional and legal framework of inter-state relations shaped their strategy and argumentation. It analyzes the causes and factors involved in the decision-making process focusing on the way previous political experiences - with both the Soviet Union and not only- shaped their perception of international relations, their vision of the CSCE and also the manner in which the party leadership chose to define Romania's interests in the institutional framework of the CSCE.

The first section of the study deals with Romania's vision of détente in the context of the CSCE and how the Romanian political elites envisaged the connection between the two processes. The second section explores Romania's reluctance to accept the bipolar vision in which the Soviet Union

Dragomir (2012): 120.

6 Wenger (2004): 22-74. 
approached the CSCE while the third section analyzes Romania's relations with Western Europe and its quest for common ground against the pressures of bipolarity. The period of reference is 1972-1975 covering the negotiation of the CSCE from its beginning to the signing of the Final Act in Helsinki.

\section{THE MULTIPLE MEANINGS OF INTERNATIONAL DETENTE}

The period which immediately preceded the debut of the CSCE process (1969-1972) was extremely tense in Romanian-Soviet relations. N. Ceaușescu of Romania had just condemned the Soviet-led intervention in Czechoslovakia much to L. Brezhnev's fury and later in 1969 postponed the party congress to which the Soviet leader was invited in order to welcome American President Richard Nixon to Bucharest ${ }^{7}$. In spite his efforts to appease the Soviets, N. Ceaușescu caused even more discontent in Moscow when he decided to visit China in 1971, at the height of the Sino-Soviet split ${ }^{8}$. Though it appeared as Ceaussescu was determined to disgruntle the Soviets by any means, this series of events was only a manifestation of a well-considered strategy. Understanding it is essential in order to observe the changes which occurred after 1972.

What did the Romanian leaders want after all? Most authors agree that the Romanian Communist elites perceived the reforms N.S. Khrushchev implemented as a hazard to the regime's stability and therefore tried to consolidate their regime independently from the USSR'. Later evolutions such as the disputes regarding CMEA reformation or the Sino-Soviet split only served to shape and encourage the Romanian course towards a form of national-Communism. But in light of Moscow's reaction towards Tito or Mao, the Romanian leaders were well aware of the risks involved by their opposition to the Soviet Union and this is why they tried to maintain good relations with the Soviets as much as it was possible. While Tito and Mao went for a full confrontation leading to ruptured relations, neither Gheorghiu-Dej nor Ceaușescu were willing to go that far.

Both PCR leaders chose to self-censor their attitude in times of crisis for two different reasons acting concurrently: on one hand, they could not afford to confront Moscow as the Chinese did since Romania was much more vulnerable and, on the other hand, their allegiance to Communism was just

\footnotetext{
Pechlivanis (2017): 241-258.

Watts (2012): 2-3.

Tismăneanu (1991): 34; Dragomir (2014): 37-42.
} 
as strong as Mao's while ideological and political affinities did have a saying in the decision-making process. Considering what happened in Hungary in 1956 and also in Czechoslovakia in 1968, it was evident that the Soviet Union maintained both the determination and the capacity to impose its will upon its satellites. From that point of view, the regime in Romania was vulnerable to Soviet interference and could not advance on an independent course too far. Reducing such a vulnerability was a primary objective of the regime in Bucharest ${ }^{10}$. Given their determination to pursue Communism at all costs, the Romanian Communist elites envisaged their autonomy in the Soviet bloc only in Communist terms and relying on a Communist argumentation. Nuances are useful in better understanding the views of the elites in Bucharest: the Declaration of April 1964 did not proclaim Romania's neutrality between Moscow and the West, but between Moscow and Beijing; when confronted with Soviet accusations of "national narrow-mindedness" the Romanian ideologists argued by quoting Lenin ${ }^{11}$.

In this context, Romania's flirtation with the West was only instrumental and did not reflect real affinities. Strong commercial ties with the West released at least part of the Soviet pressures exerted through the Council of Mutual Economic Aid (CMEA) because Romania was becoming less dependent on Soviet supplies of either raw materials or technology — just as Tito chose to work with the Americans while under Stalin's ideological fire. Increased international visibility and integration in world institutions also served to consolidate the regime and make it immune to Soviet interference while domestically the same purpose was pursued through instrumentalization of nationalism ${ }^{12}$. From this point of view, East-West dialogue involved both challenges and opportunities for the Romania. It allowed for a much greater freedom in developing trade and political contacts with the West especially since most Eastern bloc countries, confronted with the limits of extensive growth, were looking to increase their trade in cooperation with the West and so Romania's policy did not necessarily stand out as singular ${ }^{13}$. Also, Western governments seemed much less reticent than before in establishing contacts and advancing various forms of cooperation. Apart from that, though, the East-West dialogue and the later Soviet-American detente raised

\footnotetext{
10 Tismăneanu (2003): 168-169.

11 Declarație cu privire la poziția Partidului Muncitoresc Român în problemele mişcării comuniste şi muncitoreşti internaționale adoptată de Plenara lărgită a CC al PMR din aprilie 1964, Bucureşti: Editura Politică (1964): 55-56.

12 Petrescu (2009): 523.

13 Miklóssy (2011): 159.
} 
many concerns in Bucharest deriving mainly from its presumptive bipolar character.

Romania first objected to the perspective of Soviet-American agreements with worldwide consequences during the negotiation of the Nuclear Nonproliferation Treaty of 1968, accusing the fact that small non-nuclear states were not involved in the negotiations but had to obey the provisions of the treaty nonetheless which caused a legal inequity. The formulation of the Brezhnev doctrine reminded the Romanian Communist Party that Soviet control over Eastern Europe remained just as strong as before and, when American President R. Nixon visited Moscow and signed SALT I, decision-makers in Bucharest became convinced that the two superpowers were deciding the fate of the world once again on bases of spheres of influence ${ }^{14}$. The very idea of spheres of influence involved consolidated Soviet control over Romania - exactly what the regime in Bucharest had been fighting to prevent. In such circumstances, playing the Chinese card against the Soviets became redundant, just as approaching the West in order to gain more independence.

Romania could not exercise any influence on the Soviet-American detente but that was not the case with the CSCE. The CSCE involved a different framework which included small and medium states and facilitated - at least theoretically - cooperation between all those European states opposing the Soviet-American hegemony of Europe. The CSCE also had a symbolic value as it was called upon to settle unresolved issues originating in the end of the Second World War where the postwar bipolarity historically originated. This is why the CSCE was regarded as an environment able to foster solutions against hegemony, against the Brezhnev doctrine and also against the risks of a virtual Soviet-American co-dominium. At the same time, the Romanian decision-makers thought that the CSCE process also involved the risk of confirming hegemony and bipolarity should small and medium states refrain from advocating their cause. In other words, the CSCE was regarded by Bucharest as an open battle offering at least the chance to secure the regime's independence from Soviet (or foreign) interference by contributing to a redefinition of international relations in Europe on different bases ${ }^{15}$.

In its effort to fight off Soviet hegemony, the Romanian approach to the CSCE disregarded an issue that was going to gain great prominence in the future: human rights. While the Soviet Union's primary goal was to obtain recognition for its postwar borders, the Western governments, pressured by

14 Dragomir (2014): 124.

15 Wenger y Mastny (2008): 11. 
the public opinion but not only, focused on the so-called $3^{\text {rd }}$ basket which later translated into the $7^{\text {th }}$ principle of the "Helsinki Decalogue", namely respect for human rights and fundamental freedoms ${ }^{16}$. As Andrei Zagorski emphasized: "the ground-breaking role of the CSCE was not in introducing the principle of the respect for human rights as a norm but, rather, in including it on the agenda of East-West relations and committing the Eastern bloc countries to it" 17 . The Communist countries of the East finally accepted this compromise relying on the assumption that the respect for human right would remain the sole attribute of each state, failing to grasp the long-term implications of such a commitment ${ }^{18}$. The Romanian policy-makers ignored the potential effects on their regime as well and chose to focus on political and economic issues instead. Paradoxically, the human rights issue would become the most important topic in the Helsinki process after the signing of the Helsinki Accords in 1975 and Romania itself became a primary target of Western criticism for human rights abuses ${ }^{19}$.

The Romanian position at CSCE was formulated for the first time in November 1972 when the party leadership, following proposals from the MFA, approved the mandate of the Romanian delegation which was going to participate at the first meeting at Dipoli in Espoo. The Romanian position per $s e$ was the result of a long decision-making process, adapted to various circumstances along the duration of the CSCE but its basic tenets, as formulated in November 1972, remained unchanged. The mandate focused on: equality and equal rights for all participating states (which had to be reaffirmed at all times both through the principles formulated in official documents and through the procedures of the meetings); refraining from the threat or use of force in inter-state relations; the establishment of a permanent organism in charged with monitoring the outcome of the conference and the application of its decisions; economic cooperation among states with different systems in Europe $^{20}$.

Later clarifications added to the original document in 1973 as well as the directives elaborated for the second phase of the CSCE laid great emphasis on three aspects in particular: military, economic and institutional. In April 1973, new instructions sent to the Romanian delegation at CSCE insisted on refraining from the threat or use of force and tried to promote additional

\footnotetext{
Morgan (2020): 140.

Zagorski (2018): 19.

Heraclides (2014): 2.

González Aldea (2008): 44 et passim.

ANR, fund CC al PCR, section Chancellery, dossier no. 126/1972: 63-72.
} 
measures aimed to enforce the principle, such as the obligation of a government to announce its military maneuvers and avoid military exercises or maneuvers anywhere near its borders ${ }^{21}$. The mandate for the second phase of the CSCE, while reiterating the priorities formulated before, stressed out the need to overcome economic barriers in Europe. The Romanian delegation was requested to promote a general framework of European economic cooperation across ideological borders aimed at increasing not only the volume of trade but also to facilitate technical cooperation between different countries ${ }^{22}$. It obviously referred to the European Economic Community (EEC). As for the institutional component, Romania was one of the most active promoters of a permanent organism in charged with supervising the decisions of the conference and employed great efforts to popularize the idea among the participating parties. Ceaușescu himself raised the issue during talks with other chiefs of states or governments and tried to convince them all of the benefits of such an organism. He also tried to convince Brezhnev to accept the idea. The mandates of all Romanian delegations at every phase of the CSCE included this provision which the Romanian diplomats defended during meetings, as shall be detailed further on.

This tridimensional orientation of the Romanian position was designed to safeguard the country against foreign interference by reshaping the system of inter-state relations in Europe on bases different from bipolarity. Although the principles as such had a universal value and might had been applicable to the situation in Europe, what the Romania pursued were guarantees against what it perceived as bipolar hegemony reinforced by the Soviet-American detente. The military components were aimed to neutralize the Brezhnev doctrine while economic cooperation across the Iron Curtain was aimed to provide a safety valve against Soviet pressures. A permanent organism was intended to generate restraint among the superpowers and offer international countenance in case of aggression. It was, obviously, a very generous endeavor in which the Romanian leaders understood that their position clashed with the Soviet view of the CSCE but N. Ceaușescu hoped he could rely on the Western Europe in order to defend similar principles. He therefore had to fight on two fronts.

As it became clear soon after the debut of the CSCE process in 1972, the first major challenge Romania had to face was to resist Soviet pressures for uniformity. Only a week before the preparatory consultations in Dipoli, the Soviet ambassador in Bucharest invited the Romanian deputy minister of

21 ANR, fund CC al PCR, section Chancellery, dossier no. 74/1973: 10-11.

22 ANR, fund CC al PCR, section Chancellery, dossier no. 133/1973: 51-52. 
foreign affairs to a meeting in Moscow in order to participate, along with the other Warsaw Pact countries, in "elaborating the details concerning the common tactical line of the brotherly Socialist countries" 23 . It was only the first of a long series of invitations aiming to insure uniformity in the bloc. As Marie-Pierre Rey noticed, the debut of the CSCE process was accompanied by a real Soviet offensive in terms of control over both Soviet society and the Eastern European satellites. Moscow was afraid, Rey argued, that detente and the CSCE were going to encourage centrifugal tendencies in the Warsaw Pact and therefore tried to contain any independent initiative while making sure that its satellites only advanced ideas and proposals that were discussed with the Kremlin beforehand ${ }^{24}$. How did the Romanian leaders react to this strategy?

The mandate of the delegation which was going to travel to Moscow for the above-mentioned Warsaw Pact meeting reveals in a simple form exactly how Bucharest hoped to hold out to Moscow on this matter. The mandate specified, among numerous other things, that if Moscow were to suggest that all Warsaw Pact countries should consult before any decision and only advance common initiatives, the Romanian delegation had to reject the suggestion arguing that such an approach would only determine NATO countries to react in a similar manner therefore compromising the conference's chances of success $^{25}$. Surely, it was only a trick of argumentation, but it is conclusive because it demonstrates the careful rope-dancing Romania had to perform in order to maintain their position without antagonizing the Soviets beyond a reasonable limit.

In January 1973, the foreign ministers of all Warsaw Pact countries met in Moscow to discuss the reduction of troops and conventional arms in Europe - a topic of Soviet-American disarming negotiations, but also the progress of the CSCE. The Romanian delegate, George Macovescu, reported back to Bucharest that this time it was the Polish delegation which insisted that all Warsaw Pact countries should coordinate their positions at CSCE. Macovescu also noticed that in all Soviet speeches or projects, the issue of refraining from the threat or use of force was condoned; when Macovescu approached Soviet foreign minister A. Gromyko on this topic, his answer was rather evasive ${ }^{26}$. In May 1973, the Soviet initiatives continued with another meeting of the deputy foreign ministers where the Soviet host, N.N.

ANR, fund CC al PCR, section Chancellery, dossier no. 126/1972: 45.

Rey (2008): 76-77.

ANR, fund CC al PCR, section Chancellery, dossier no. 126/1972: 50-51.

26 ANR, fund CC al PCR, section Foreign Relations, dossier no. 248/1973: 2-6. 
Rodionov, insisted that all Socialist countries must consult each other in any matter concerning the CSCE. Furthermore, he insisted that any document or proposal submitted to the conference by a Warsaw Pact country had to be coordinated with the USSR. Rodionov even suggested that it was better to leave any initiative to the USSR but, for the sake of appearances, he seemed to agree to the idea that it was perhaps better that some initiatives agreed upon to be forwarded by other Socialist countries ${ }^{27}$.

It was not a secret that Moscow had its own particular agenda at the CSCE, concerning mostly the recognition of postwar borders, and that Soviet leaders expected their satellites to just follow in line. Many of these satellites had their own agenda - although the matter is still under-researched - but avoided a clash with the Soviets on this matter for various reasons ${ }^{28}$. Poland's fear of a possible German reunification affecting its security interests is a good example in this sense ${ }^{29}$. As Wanda Jarzabek argued, the CSCE was very important to Poland because, on one hand, it included promises of economic cooperation which were vital for Warsaw given the USSR's inability or unwillingness to satisfy Polish economic demand and, on the other hand, because a general framework such as the CSCE would have prevented Poland from being "betrayed" by the Soviet Union through a separate Soviet-West German agreement on borders ${ }^{30}$. Both Poland and East Germany feared that Moscow could have reached an agreement with Bonn on the Oder-Neisse border without consulting them. Walter Ulbricht of East Germany had been insisting long before 1972 that a recognition of the status-quo in Europe be reached as a precondition to the start of a European conference but was opposed by Brezhnev and Ceaușescu ${ }^{31}$. The issue was settled, though, after the PolishWest German Treaty of 1970 and the Basic Treaty between the two German states was signed in 1972 , both providing for the recognition of the postwar borders.

In July 1972, during the informal Yalta meeting, L. Brezhnev stated clearly that the Warsaw Pact's most important goal at the CSCE was the recognition of postwar borders ${ }^{32}$. While this was a matter of great importance for the USSR, as well as for the former victims of Germany (Poland, Czechoslovakia) and East Germany, it had little relevance for countries such

Ibid.: 27-28.

Wenger y Mastny (2008): 12.

Jarzabek (2008): 38.

Ibid.

Morgan (2020): 82.

32 ANR, fund CC al PCR, section Foreign Relations, dossier no. 80/1972: 18. 
as Hungary, Romania or Bulgaria. Both Romania and Hungary, for example, were losing territories (Romania lost Bessarabia to the USSR, Hungary lost Transylvania to Romania). A Western recognition of this status quo did not amount to anything. What Moscow offered to its allies as a result of the CSCE was the surplus of security deriving from a general agreement with the West, as well as more economic opportunities. In exchange for that, Moscow requested conformity.

The following year, the informal Yalta meeting took place right between the first and the second phases of the CSCE. L. Brezhnev reiterated once again that recognition of borders was the most important goal of the Warsaw Pact at the CSCE. Also, he added, the West was trying to take advantage of the Socialist countries by speculating the differences that might exist between them and that was why, in Brezhnev's view, the Socialist countries had to demonstrate unity and solidarity in all their initiatives ${ }^{33}$. Nicolae Ceaușescu attended that meeting but chose not to reply to this. Instead, he replied to Brezhnev's warning regarding the risks involved by the so-called $3^{\text {rd }}$ basket for the Socialist countries. Ceaușescu claimed that he did not fear human contacts at all but, on the contrary, Socialist countries should focus their efforts in a different direction: "today, through the modern means of television, radio, through the satellites mentioned $\mathrm{cmd}$. Brezhnev which make America's television programs known all over the world, we can no longer prevent this exchange of ideas and opinions. The problem is that we must act in such a way, through our educative, ideological activity, through our cultural work, through everything we do, so as to demonstrate the superiority of socialism" ${ }^{34}$.

As far as the Romanian views on international relations were concerned, these were in a process of transformation at the time. Independence in foreign policy was no longer regarded in Marxist-Leninist terms, in the framework of the world Communist movement, but the focus was slowly shifting towards juridical, non-ideological terms in the geographical framework of Europe. In June 1973, a series of meetings of the party leadership illustrate well this process of transformation. On 25 June 1973, the Party Presidium rejected a Soviet proposal according to which Warsaw Pact ministers of foreign affairs were supposed to meet separately in Helsinki. N. Ceaușescu stated on that occasion, with visible frustration, that Romania could not accept just any proposal advanced by just any section of the Central Committee in Moscow. Furthermore, he added, the purpose of the CSCE should be exactly the

33 ANR, fund CC al PCR, section Foreign Relations, dossier no. 140/1973: 21-25.

$34 \quad$ Ibid.: 187. 
opposite: "Europe must become a force in itself against the diktat of the two superpowers" ${ }^{\prime 3}$. Emil Bodnăraş, a veteran member of party leadership, also stated, just as determined, that Moscow may wish to have its own borders recognized but the CSCE was about much more than that and Romania for one could no longer accept formulas based on distinctions between winners and losers of the Second World War ${ }^{36}$. The political implication of his statement shall be explored in the following section of the article.

An interesting debate took place on 20 August 1973, after the summer Yalta meeting. As the CSCE negotiations were making progress, it was Emil Bodnăraș again who raised the issue of the frontiers. Referring to various versions of documents discussed at the CSCE, Bodnăras, expressed reserve towards the inviolability of frontiers as a principle. He argued that Moscow was interested in that because it just wanted to consolidate the territorial conquests it made during the war but Romania did not share such interest; even more, negotiation on the delimitation of the continental plateau of the Black Sea - in which Romania was indeed very interested- would be hindered by the principle of frontier inviolability ${ }^{37}$. N. Ceaușescu rejected his objection though with an interesting remark: "I don't plan to raise the Bessarabia issue tomorrow. This is the situation according to today's conditions. What will be in 15 years, we'll see then" ${ }^{\prime 8}$.

Apart from the technicalities of frontier inviolability, it is visible that the party leaders in Bucharest were reevaluating — once again after 1964 - their relation with the Soviet Union, without any inhibition and without any regard for the taboos of inter-bloc relations. The CSCE was an opportunity to resettle relations in Europe on new bases and they wanted to make sure that those bases would be beneficial to Romania. If this resettling required official narratives of the postwar world order to be altered decades after 1945 by arraigning vital Soviet interests, the Romanian leaders seemed determined enough to do it.

\section{THE SPIRIT OF POTSDAM}

During the most intense phase of the CSCE negotiations (1973-1974), Romanian-Soviet divergences were never discussed in depth at any bilateral

ANR, fund CC al PCR, section Chancellery, dossier no. 117/1973: 23.

Ibid.: 21.

ANR, fund CC al PCR, section Chancellery, dossier no. 133/1973: 21.

Ibid.: 22. 
meeting. N. Ceaușescu met L. Brezhnev on several occasions during this time and yet the CSCE was only approached formally in their talks. The two leaders appeared willing to transfer their disagreements to lower level officials in order to spare their relations of more tension. It is also interesting that, in matters concerning Romania's relations with China, Brezhnev always confronted Ceaușescu openly during their talks, never missing a chance to express his discontent, always oscillating between promises and threats (either explicit or implicit $)^{39}$. Brezhnev chose not to follow such a course in the CSCE context — probably because he had already discovered that pressuring Ceaușescu on such topics was ineffective. This is why the Romanian-Soviet disputes on matters of hegemony and superpowers took place in either Helsinki or Geneva, between heads of delegations or other officials while each side continued to promote its own vision independently.

What the Romanian party leadership disliked terribly in the Soviet approach was the continuous reference to Potsdam. This was the key to the Soviet view on the CSCE because it invoked a special, different role for the Union in Europe, deriving from the Second World War, from the victory and the responsibilities (as occupying power) which Moscow saw as deriving from victory. It placed the Soviet Union at a different table together with the other victorious powers rendering the equality of all states futile. George Macovescu, the Romanian minister of foreign affairs, noted in his report on the first phase of the CSCE that his Soviet homologue, Andrei Gromyko, insisted on the fact that European security can only rely on the Potsdam agreement ${ }^{40}$. Macovescu also noted that both the United States and the Soviet Union emphasized the role of the superpowers in constructing security in Europe and appeared to disregard the role of small and medium states. The Romanian delegate was careful to notice that Gromyko also specified in his address that he was speaking on behalf of the "Socialist community, its allies and friends", assuming a role that was not given to him, at least not by Romania $^{41}$. It was the bloc-to-bloc approach that N. Ceaușescu was trying to undermine.

For the Romanian decision-makers, it became evident especially during the second phase of the CSCE that Moscow relied on its agreement with the Americans in advancing a bipolar vision on European security and detente. It was probably the reason for which Brezhnev chose not to pressure Ceaușescu much: he had a bigger scheme on his mind. Still, America's lack of interest in

39 Stanciu (2013): 353-372.

40 ANR, fund CC al PCR, section Foreign Relations, dossier no. 237/1973: 31.

41 Ibid. 
the CSCE process was visible in its bilateral relations with the Soviet Union as well. When H. Kissinger visited Moscow in May 1973, the suggested to the Soviets that the obstacles encountered by the CSCE were caused by the large number of governments involved in the negotiations. He was evidently suggesting that a bilateral Soviet-American approach would have been much more convenient which was exactly what the Soviets thought too. Also, when L. Brezhnev visited America later that year, he and Nixon did not discuss the topic at length. R. Nixon's informal position was that he was unable to force his Western allies into anything ${ }^{42}$. It was evident that both Washington and Moscow preferred a bilateral superpower agreement although the first was reluctant on the topic and the later tried not to push things too far.

But Ceaușescu was not going to quit so easily. In the following year and a half, he focused the entire Romanian diplomacy on pressuring both the Soviets and the Americans but especially the Western European delegations and governments to accept small changes in the documents of the conference with the purpose of diluting references to bipolarity. The Romanian diplomacy did have a rhetoric advantage: the concept of the CSCE was first formulated in 1966 and 1969, long before the rise of international detente with R. Nixon's visit to Moscow in 1972. It is important to notice that the Soviets were much more willing to discuss equality among all states before 1972, a fact that was recorded in the documents of the Bucharest and Budapest conferences of 1966 and 1969. That was enough to offer the Romanian diplomats arguments against the Soviet position as it had been formulated by A. Gromyko in 1973.

Valentin Lipatti, head of the Romanian delegation at CSCE, approached the Soviet delegation in November 1974 in Geneva, inquiring directly about the Soviet reticence in accepting the principle of equality for all states. His argument was that the Declaration of Bucharest in 1966 as well as the Appeal of Budapest in 1969, both signed by the Soviets, included this provision. Lev Mendelevich, deputy head of the Soviet delegation, offered a direct answer on that occasion, which was rather rare in mutual consultations. Mendelevich told Lipatti that the Soviet Union could not accept the equality of all states simply because the states were not equal in fact. Some of them, he argued, were members of the Security Council of the United Nations and had certain responsibilities while others were not and their responsibilities were much more limited ${ }^{43}$. He also added bluntly that, in Moscow's view, there was no such thing as an "international community" but there were two

42 Hanhimäki (2003): 44-46.

43 ANR, fund CC al PCR, section Foreign Relations, dossier no. 328/1974: 22-23. 
communities, one of Socialist states and the other of capitalist states. Any state finds its identity and independence only inside the community to which it belongs, lectured Mendelevich, and therefore European security can only rely on this premise. Furthermore, he confessed to Lipatti, Moscow instructed its delegation to oppose any stipulation that states have equal obligations -only equal rights perhaps - as well as "the right to free existence". The Soviet would not accept the concept of "personality" applied to states, either, Mendelevich also said ${ }^{44}$.

A week later, on 28 November 1974, V. Lipatti approached A.G. Kovalev, head of the Soviet delegation, to discuss the Romanian proposals regarding the threat or use of force. Romania wanted the conference to adopt a set of effective measures aimed to protect states from the threat or use of force and the Soviets were, as expected, reluctant. Lipatti explained Kovalev that the principle in itself had already been agreed with Moscow on previous occasions and there were numerous documents signed by the Soviet leadership reaffirming the USRR's commitment to the principle. A.G. Kovalev explained that, in spite all that, he had instructions from Moscow to oppose the Romanian initiative ${ }^{45}$. Lipatti inquired about the causes of such an attitude and Kovalev, reluctantly, offered two basic causes: on one hand, the USSR had obligations deriving from the Potsdam agreement and from the Quadripartite agreement on Berlin which may involve the use of force under certain circumstances and, on the other hand, the United Nations Charter stipulated at article 53 the right of the victors to use force against the former enemies under given circumstances ${ }^{46}$. Therefore, the threat or use of force, Kovalev concluded, could not be envisaged only in principled terms as the Romanian diplomacy described it, but had complex juridical and military implications that could not be resumed in a simple phrase.

The argument invoked by Kovalev was extremely delicate for Romania as it had been an enemy state in the Second World War and article 53 of the UN Charter concerned it directly. N. Ceaus,escu denounced this approach at the $11^{\text {th }}$ party congress in November 1974 where he stated that European security depended on the measure in which each state felt safe from foreign interference. "Achieving European security is incompatible with the existence of opposing military blocs", he also added ${ }^{47}$. These theses were later

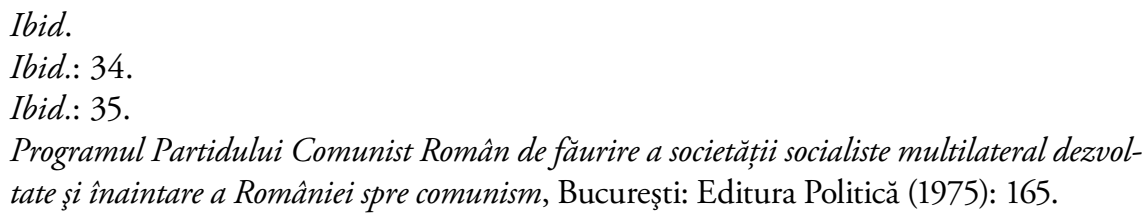


published in the PCR party program — the first and the only party program ever to be elaborated by the Romanian Communists. The Soviet delegation present at the congress, headed by A.P. Kirilenko, did not miss the chance to tell Ceaușescu that this was precisely the reason for which L. Brezhnev refused to visit Romania: the Romanian Communist Part always had distinct points of view on mostly everything and the trust was missing between the two parties. Moreover, the Romanian attitude only helped the enemy to find arguments against Socialism, Kirilenko added ${ }^{48}$. Ceaușescu did insist on having Brezhnev in Romania for a visit as a sign of reconciliation after the clash of 1968 but the Soviet leader kept postponing. Kirilenko's replica did not go unsanctioned as Ceaușescu had a rather "sharp mouth" himself: this is not how the Romanian party leadership envisaged party to party relations, he said, but relations among Communists should be based on the premises which led to the dissolution of the Komintern. Once again he used a Soviet decision as argument against the Soviets but, in the end, this dialogue led nowhere. It appeared that there was not much place for compromise between the two sides.

But the Romanian leaders did have an ace up their sleeve: the other superpower. Romania continued to improve its relations with the United States after 1967 because of its role as a mediator between the Americans and the Chinese and later due to its mediation in the Middle East crisis. Although Romania never assumed the role of mediator in Sino-American relations, the fact that Washington often transmitted top secret messages to the Chinese through the Romanian channel certainly had a major effect of mutual relations and helped build trust and confidence in Romanian-American relations. As the CSCE process was progressing in 1974 and the Romanian initiatives did not appear to advance, decision-makers in Bucharest decided to approach the United States for support. The American lack of interest in the CSCE process was already known at the time but $\mathrm{N}$. Ceaușescu hoped to convince White House officials relying on their understanding of Romania's position in relations with the USSR. From this point of view, N. Ceaușescu had a very good relations with R. Nixon and was hoping for the same in relation with Gerald Ford.

Shortly after Gerald Ford took office following Nixon's resignation, Romanian Ambassador to Washington, Corneliu Bogdan, visited the President to congratulate him and took the opportunity to approach the delicate CSCE issues. Corneliu Bogdan emphasized how important it was, from the Romanian perspective, for the United States to increase its involvement in

48 ANR, fund CC al PCR, section Foreign Relations, dossier no. 368/1974: 20-21. 
the CSCE process ${ }^{49}$. Altought Bogdan did not refer to the human rights issue, Henry Kissinger, who also took part in the meeting, stated that the United States considered the "human contacts" issue to be holding back the progress but the White House was not interested to waste its political capital in Western Europe on such a matter. The United States, Kissinger said, did not believe that matters such as human contacts could change the political system in Eastern Europe and was therefore irrelevant; moreover, Western Europeans insisted on the matter because of domestic reasons which was, again, irrelevant for the United States. The Americans, he said, were surprised that the conference advanced so much in the first place ${ }^{50}$.

Corneliu Bogdan reminded Ford and Kissinger of the Romanian proposal regarding the establishment of a permanent organism responsible for monitoring how the conference decisions were applied. He did not have to stress out why the organism was important for Romania as Kissinger understood, without much ado, that Romania imagined the organism as a defense against Moscow. At that time, N. Ceaușescu and the party leadership did not anticipate that such an organism, once established, could have been used against its own regime as it later happened when the Helsinki follow-up meetings focused especially on human rights putting Romania in a defensive position due to its human rights abuses. It results clearly from Bogdan's conversations with his American counterparts that the Romanian leadership only envisaged the idea of a permanent organism in charged with defending the principles of the conference only as a safeguard against Soviet interferences. It is worth mentioning that other Eastern countries embrac ed such a vision as well: Poland, for example, as Csaba Békés noticed, supported the idea of institutionalization hoping that it would provide more leverage for small and medium states against the superpowers ${ }^{51}$.

During the above-mentioned conversation, Kissinger explained Bogdan that the White House was aware of the reasons for which Romania promoted the idea of a permanent organism and empathized but the implications of such an organism could be detrimental to the United States. An organism capable of protecting Romania against Soviet aggression may also be capable of interfering in Western Europe and that was unacceptable for the Americans. H. Kissinger did add that he was not reticent to the idea in itself and may be willing to analyze favorably a different formula which could satisfy Romania's security needs without interfering with American interests ${ }^{52}$.

\footnotetext{
ANR, fund CC al PCR, section Foreign Relations, dossier no. 359/1974: 26-27.

Ibid.: 4-6.

Békés (2008): 155.

52 ANR, fund CC al PCR, section Foreign Relations, dossier no. 359/1974: 6-8.
} 
N. Ceaușescu discussed these problems with Henry Kissinger in November 1974 when the secretary of state paid a short visit to Romania. Ceaușescu insisted to explain that Romania expected the conference in Europe to settle everything that was left unsettled after the war and reminded him of article 53 of the UN Charter which permitted military intervention in the "former enemy states". Kissinger claimed to be unaware of the implications. Ceaușescu further explained that Romania, as a former enemy state, did have a peace treaty with the United Nations signed in 1947, but article 53 of the UN Charter still remained valid as it had been introduced in the document before the peace treaties of 1947 were signed. In this case, although the juridical implications of the situation were complicated, article 53 of the Charter still offered at least the pretext for foreign intervention, if intervention was really wanted. Kissinger confessed that he never saw things that way and promised to look into the matter much more carefully ${ }^{53}$.

Furthermore, Ceaușescu lectured Kissinger on the need to involve all countries in the process of detente and argued that a bipolar detente reminded him of something else, of a historical event with disastrous outcomes: "I remember — and you must know it well - what happened in 1939. Stalin preferred an agreement with Hitler. It was written that it was an agreement for a thousand years but we know how much it lasted and what the consequences were. We know the United States cannot be compared with Germany but the danger of an agreement between two parties is visible to all countries in Europe, even by your best allies" ${ }^{\prime 4}$. Kissinger denied having such intentions and replied that what displeased Western Europeans was that they missed the chance to reach an agreement with Moscow before the Americans. Ceaușescu once again implied that America's behavior as superpower may have pushed them towards such solutions. Ceaușescu urged Kissinger to increase America's involvement in the CSCE process in order to encourage a multilateral process of detente and Kissinger - either complacently or not- accepted that he needed to reflect more on Ceaușescu's warning and reconsider the American participation in the $\mathrm{CSCE}^{55}$.

Since Moscow's influence in East Central Europe was based on the results of the Second World War, the Romanian leadership calculated, any political or symbolic step proclaiming the end of the post-war realities and the beginning of a new age in international relations would therefore undermine the Soviet moral justification for hegemony. It was one of the stakes of Ceaușescu's talks

53 ANR, fund CC al PCR, section Foreign Relations, dossier no. 364/1974: 12.

54 Ibid.

55 Ibid.: 13-14. 
with the Americans, but Ceaușescu had other stakes as well. His highest bid was to attract the Western Europeans in an anti-hegemonic scheme.

\section{ROMANIAN-WEST EUROPEAN RELATIONS IN THE CONTEXT OF THE CSCE}

Western Europe was going through a process of transformation in the second half of the 1960s which encouraged the Romanian leaders to think that new partnerships were becoming possible in the future. N. Piers Ludlow argued that, starting with the 1960s, Western Europeans began to reject American control because of their growing self-confidence generated by the success of postwar reconstruction and European integration, but also because the American involvement in Vietnam ${ }^{56}$. A growing self-confidence is also visible in the Romanian case when, after years of neutrality in the Sino-Soviet split, Bucharest dared to go even further in its defiance of Moscow, as was the case with the condemnation of the Soviet-led intervention in Czechoslovakia. Jussi Hanhimäki also noticed that "the caricature-like division of Europe and the world did not always conform to the interests and aspirations of individual nations and their leaders"57. A good example in this sense is the "Harmel Report" elaborated in 1967 which recommended NATO to pursue a two-track policy towards the Warsaw Pact, combining military defense with political detente ${ }^{58}$.

For Romania, Neue Ostpolitik was a major turning point. Romania was the first Warsaw Pact country to react favorably to Willy Brandt's initiatives even before he became chancellor and advocated in favor of a positive response among other Warsaw Pact members ${ }^{59}$. Neue Ostpolitik was very significant for Romania because of two basic reasons. On one hand, the logic of this new West German approach, as emphasized by numerous authors, was that the Communist bloc was behaving aggressively because it felt insecure, it reacted to pressure and isolation from an unfriendly outside world; changing that, the West German social-democrats thought, offering recognition, security and "normalization" to the Communist bloc would change its behavior accordingly ${ }^{60}$. Trying to escape Soviet dependence, this was exactly what Romania

\footnotetext{
Ludlow (2010): 193.

Hanhimäki (2010): 201.

Hanhimäki (2003): 39.

Stanciu (2015): 88.

Cary (2000): 370.
} 
was looking for: a friendly, "normal", attitude that would foster constructive relations. On the other hand, Neue Ostpolitik was a proof of independence on part of the West Germans. It was practically the first major step undertook by a Western government in East-West relations which was not coordinated with the United States, which offered a multilateral meaning to the East-West dialogue and, just as gaullism, was the expression of Europe's demand to have a say in its own future ${ }^{61}$.

Perhaps it was just "wishful thinking” on part of N. Ceaușescu but his presumption was that Western Europe was just as displeased with the American hegemony as Romania was with the Soviet hegemony. It was later along the process that he discovered how evolutions in the West were only partially similar and convergent with evolutions in the East and the partnership against hegemony that he was looking could not go as far as he imagined. In any case, $\mathrm{N}$. Ceaușescu relied on the fact that Romania's struggle against hegemony would go hand in hand with that of Western Europe. In May 1968, for example, he was recounting enthusiastically to I.B. Tito of Yugoslavia his meeting with French President Charles de Gaulle only days earlier. France, he told Tito, promotes a different understanding of European security, one based on the independence of each state, one that includes the Socialist states of Eastern Europe too and the existence of both German states, even though de Gaulle - Ceaușescu added — was not in the position to assume publicly all the implications of his ideas ${ }^{62}$. He also shared with Tito his impression that such preoccupations were visible among most European governments and, combined with what he saw as the "radicalization of the public opinion" in the West, represented a good starting point for a new approach to European security ${ }^{63}$.

But the progress of the European economic integration in the West represented a major challenge for the Romanian vision on East-West anti-hegemonic collaboration and did not fit into Ceaușescu's plans. Romania needed Western Europe for economic reasons too because trade and economic cooperation outside the Communist bloc were a safety valve for Romania which was subjected to Soviet pressures within CMEA. Ceaușescu's opposition to Moscow depended on the way he managed to find economic alternatives. As early as 1967 he told a French Socialist delegation led by Guy Mollet that unification was not yet possible in the West nor in the East and that was why the Common Market only obstructed cooperation instead of facilitating

\footnotetext{
61 Sarotte (2008): 154.

62 ANR, fund CC al PCR, section Foreign Relations, dossier no. 75/1968: 24-25.

63 Ibid.
} 
it. Both CMEA and the EEC, he said, were trying to impose integration by institutional means but integration could only be the result of gradual development $^{64}$. But both Guy Mollet and his colleague Christian Pineau suggested to Ceaușescu that the EEC also had a political role. Pineau told Ceaușescu that the French envisaged the EEC as a competitor to both the United States and the Soviet Union, and also as a sort of "cage" for West Germany but the Romanian elites did not seem to pay much attention to the political implications of the EEC ${ }^{65}$. Bucharest somehow presumed that the CSCE and the possibilities it opened for resettling relations in Europe would outweigh the political benefits of European integration - political benefits which they failed to see all along.

Georges-Henri Soutou pointed out that the French vision on Europe was marked by a convergence between two apparently independent evolutions: detente and European integration. The author argued that French President Georges Pompidou joined efforts for a European security conference fearing a Soviet-American or a Soviet-West German rapprochement which would place Europe under the co-dominium of those powers. Also, France saw European integration as a rampart against a bipolar Soviet-American detente $^{66}$. In Pompidou's view, therefore, the fight against hegemony was connected with the progress of European integration. This last process had the potential to consolidate the economic force of Western Europe, to encourage a sense of solidarity and mutual responsibility which in turn reduced the margin for superpower domination. This regional view on European economic cooperation represented nonetheless a major obstacle to Romania's plans to diversify its economic partners as an anti-domination strategy.

Romania was not the only Eastern bloc country interested in economic cooperation with Western Europe at the expense of the EEC. Many other Warsaw Pact countries were interested to enlarge their economic cooperation in the West and were displeased with the obstacles involved by the rather restrictive trade and tariffs policy of the EEC. Peter van Ham, for example, argues that the European Economic Community practiced a real "protectionism against East European products" which obstructed the Eastern countries from exporting on Western markets ${ }^{67}$. Already dealing with a stagnating economy, Moscow "was decreasingly able to meet" the desires for economic and technological advance

\footnotetext{
ANR, fund CC al PCR, section Foreign Relations, dossier no. 31/1967: 11.

Ibid.: 7.

Soutou (2007): 12.

Ham (1995): 86.
} 
manifested by its Eastern European satellites, as John Fry emphasized ${ }^{68}$. On the other hand, the Soviet Union regarded European integration as a risk to its position in Europe. Angela Romano pointed out that: "a strong Western Europe impeded the Soviet policy of divide et impera and represented a potential threat to Soviet hegemony in Eastern Europe, for the capability it had of appealing states to membership" ${ }^{69}$. Moscow too was interested to promote economic cooperation with the West but outside or above the regulated framework of the EEC which only caused impediments in this respect. Peter van Ham argued that the Soviet Union saw the CSCE process as an alternative to the EEC, although its view was not shared by the EEC members at all ${ }^{70}$. As far as Romania was concerned though, Soviet apprehensions were wrong: the existence of the EEC actually impeded a closer cooperation between Romania and Western Europe while being very far from exerting attraction on a regime that was, on one hand, devoted to the Stalinist model of rapid industrialization and, on the other hand, fearful of Soviet military reactions in case of an open break with Moscow. Romania too wanted to work closer with Western Europe in a framework different from the EEC, one that had to be elaborated through the CSCE or based on the CSCE principles and regarded the symbolic borders of the EEC as a confirmation of bipolarity and, in the end, of the hegemony wielded by the two superpowers. Removing borders was actually their primary goal at the CSCE although the meaning of borders and hegemony was different in Western Europe, as they soon discovered.

N. Ceaușescu talked about that to Hans Janitschek, secretary general of the Socialist International in 1973, expressing his ideas about the future of Europe outside the bipolar limitations. Europe has to devise its own security strategies, he said, must not fear the atomic bomb because it cannot bring much benefit to whoever might use it. Europe must understand, Ceaușescu

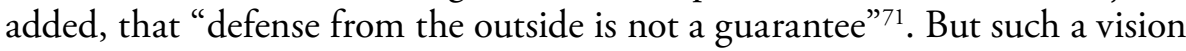
had difficulties in finding supporters in the West for various reasons. As Angela Romano also pointed out, Western Europe tried to "avoid relations with East European countries to appear as directed against Moscow" and therefore did not encourage independent initiatives coming from the East, fearing that Moscow would tighten control over its satellites and undermine dialogue $^{72}$. In the view of Western decision-makers, Romano argued, "it was

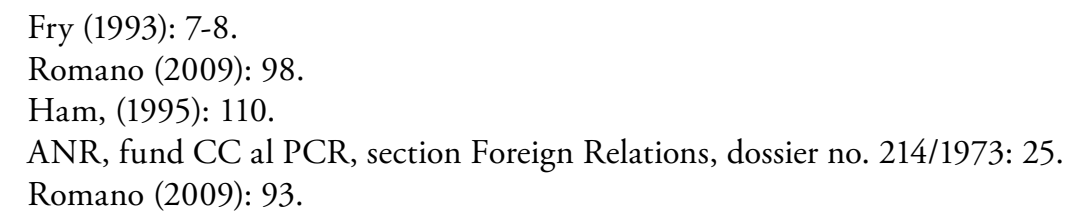


unthinkable to search for improvements in relations with the East without previous progress in the relationship with the Soviet Union"73.

Although just as determined to fight against bipolarity and the challenges of a bipolar detente, most Western decision-makers regarded this fight in different terms when compared with the Romanian leaders who practically stood out as radicals. In a meeting with the West German minister of foreign affairs, Walter Schell in November 1973, N. Ceaușescu referred to the talks on Mutual Reductions of Forces and Armaments in Central Europe underway in Vienna at the time and insisted that troops stationed on foreign territories must be withdrawn as a prerequisite of European security, as part of the Romanian vision aimed at dismantling both military blocks in Europe. Schell explained to Ceaușescu that his vision did not exactly converge with the Western view on security: "we, Europeans from the West, cannot defend ourselves from the nuclear might of the Soviet Union without the contribution of the other nuclear superpower, the United States. This nuclear protection only works as long as American troops are in Europe"74. In other words, Schell did not envisage European security above or apart from the two superpowers but only advocated in favor of a larger, multilateral framework of decision-making: not against the superpowers but together with them.

The French Socialists also shared this point of view much to Ceaușescu's disappointment. When he met François Mitterrand in May 1972 — shortly before Mitterand signed the Common Program with the Communists in the framework of L'Union de la gauche - Ceaușescu sharply criticized the EEC as an obstacle in the path of European cooperation and an expression of monopolist capitalism ${ }^{75}$. Romania's efforts to build bridges towards Western Socialism and Social-Democracy reveals a rather good understanding of political cleavages in the West. Dionyssis G. Dimitrakopoulos argued that the European left did not react positively to the emergence of the Common Market because it saw it as a creation of the right (mainly ChristianDemocracy) which tended to favor industrialists and independent farmers instead of the urban proletariat ${ }^{76}$. In this case, Romania's criticism of the EEC had better chances to strike a chord among parties of the left, such as the French Socialists. Mitterand confessed that he did share with Ceaușescu the hope to develop his country independently from the Americans so as to avoid "American economic colonization". But it was particularly from this point of

Ibid.

74 ANR, fund CC al PCR, section Foreign Relations, dossier no. 112/1973: 15.

75 ANR, fund CC al PCR, section Foreign Relations, dossier no. 35/1972: 28.

76 Dimitrakopoulos (2010): 2. 
view, he added, that the EEC had gained a complex political role in French strategies. Mitterand told Ceaușescu: "the problem for us French is to escape the current American tutelage without falling under Soviet tutelage because if we were to separate from the United States without being part of a strong community, the only real power on the continent would remain the Soviet Union"77.

Another Socialist leader, Alain Savary, explained to Ceaușescu a year before in 1971 that French Socialists did not necessarily see connections between the EEC and NATO. The Common Market, Savary explained, helped support the independence of France in front of both American and Soviet hegemony but it also served to keep Germany under control and prevent the resurgence of nationalism. Therefore, although the EEC borders partially overlapped with those of the Iron Curtain, there was a major difference of meaning between the Common Market, on one hand, and the two military blocks, on the other hand ${ }^{78}$. As Alain Savary concluded, the commitment to the EEC did not obstruct France's struggle against bipolarity and hegemony - needless to observe that it did obstruct the Romanian struggle. A similar idea was later advanced to Ceaușescu by Walter Schell. When speaking of detente, the West German minister connected it with the advance of European integration. Detente can only progress, Schell said, only as long as European integration progresses because the Atlantic framework of defense was already becoming outdated ${ }^{79}$. In this sense, he dismissed Romanian views that the CSCE and the EEC were antagonistic processes.

This difference of interpretation derive mainly from an asymmetry: Western Europe was practically a group where members were not isolated one from another and they could always fall back on a structure that represented their own interests in a form separate from the United States. Romania, on the other hand, was isolated in the Communist bloc, did not have partners to work with against Soviet domination and no structure to rely on in case of Soviet pressure. Apart from that, there were, obviously, significant differences between what American hegemony meant in the West when compared to Soviet hegemony in the East. This is why, in spite of the fact that Western Europe was indeed motivated to fight off hegemony and superpower bipolarity, the chances for Romania to work together with Western Europe and elaborate a common formula above and across the Iron Curtain - as the Romanian leaders envisaged - were remote. Up to a certain point, the Western Europeans even saw the Soviet Union as an opportunity for economic

ANR, fund CC al PCR, section Foreign Relations, dossier no. 35/1972: 33.

ANR, fund CC al PCR, section Foreign Relations, dossier no. 17/1971: 9-10.

ANR, fund CC al PCR, section Foreign Relations, dossier no. 112/1973: 9. 
cooperation and were interested to consider formulas of cooperation which would exclude the United States and offer Western Europe initiative. As Peter van Ham argued, the Western European summit of Paris in October 1972 decided that the EEC should pursue a common commercial policy towards the East in order to encourage detente ${ }^{80}$. The decision reminded of the Neue Ostpolitik spirit of offering normalization in order to open doors but it was in contradiction with Romania's approach which claimed that such decisions should be adopted by national governments instead of blocs or organizations. There was a distinct belief among Western Europeans that the Soviet Union and the Communist bloc, as European problems, should be treated by the Europeans independently from the United States - just as Charles de Gaulle tried- but this approach, as mentioned before, was in contradiction with the Romanian vision. Practically, what Western Europeans understood as independence from (American) hegemony, Romania saw as confirmation of bloc politics.

But Romania and Western Europe did agree on one important issue: delegitimizing the Brezhnev doctrine. The Soviet proposals on the renunciation to the use of force were formulated so as to permit the use of force under specific circumstances: bilateral or multilateral treaties, conventions or agreements. The aim of such formulation was to offer justification for the Brezhnev doctrine, for a Czechoslovak-like intervention in case Moscow saw it necessary. As Angela Romano argued, most Western governments understood exactly where Moscow was hinting and refused to accept such formulation asking instead for a very clear definition of renunciation to the use of force ${ }^{81}$. It was, of course, to Romania's benefit although satisfaction in Bucharest was only partial. The Final Act did maintain a reference to the Charter of the United Nations - in the sense that all signatories expressed their adhesion to it - although it was the Charter which provided for the victors of the Second World War the right to intervene in the former enemy states. It was, of course, history's task to prove which side of the glass mattered most: half victory or half defeat.

\section{CONCLUSION}

Romania saw the CSCE as a chance to politically rearrange postwar Europe so as to undermine the bases on which Soviet and American hegemony

80 Ham (1995): 110.

81 Romano (2009): 105. 
over the continent had been established. In advancing such a project, the Romanian Communist elites moved further in their anti-Soviet dissidence from the Marxist-Leninist arguments previously used to defending national Communism or to defend neutrality in the Sino-Soviet dispute to a different level of argumentation. In doing so, the party leadership in Bucharest relied on the fact that Western Europe was opposing American hegemony too and therefore a common front against bipolarity could be put together in order to transform political relations in Europe.

Romania promoted many principles and ideas at the CSCE but the most relevant of them aimed at securing the country's position in the event of a military threat deriving from the Brezhnev doctrine: at principled level, refraining from the threat or use of force and at practical level, the establishment of an organism in charged with supervising the application of the final documents. These measures (and others) were part of a wider endeavor aimed at transforming relations in Europe on bases of equality and multilateral detente instead of the bipolarity which originated at the end of the Second World War and was the source of superpower hegemony. Romania had to once again confront the Soviet Union on a different platform, challenging its position and role in postwar Europe as it had before challenged Moscow's position in the world Communist movement.

The Romanian leadership tried to secure both American and European support for their efforts (at different stages and for different purposes) but success was rather limited. This partial failure was due to the fact that Western Europe was not determined to go as far as the Romanian leaders in fighting off hegemony and bipolarity because Western Europe was simply not as affected by hegemony as Romania was. Still, Romania did not fail. Its efforts helped accelerate the fragmentation that was already manifesting in the Communist bloc, they encouraged and contributed to various evolutions directed against Cold War bipolarity and superpower hegemony (such as non-alignment or Eurocommunism) and therefore played a role - as minor as it may have been - in the ultimate dissolution of military blocs and the demise of the Cold War ${ }^{82}$. What is ironic though, is that the evolutions Romania helped put in motion turned against its oppressive regime and the end of bipolarity was also the end of the regime which so energetically fought against bipolarity.

82 Davy (2009). 


\section{BIBLIOGRAPHY}

Békés, C. (2008). The Warsaw Pact, the German Question and the Birth of the CSCE Process, 1961-1970. In O. Bange and G. Niedhart (eds.). Helsinki 1975 and the Transformation of Europe (pp. 113-128). New York; Oxford: Berghahn Books.

Bloed, A. (ed.) (1993). The Conference on Security and Co-Operation in Europe: Analysis and Basic Documents, 1972-1993. London: Kluwer.

Cary, N. (2000). Reassessing Germany's Ostpolitik. Part 2: From Refreeze to Reunification. Central European History, 33, 369-390. Available at: https://doi. org/10.1163/156916100746374.

Davy, R. (2009). Helsinki myths: setting the record straight on the Final Act of the CSCE, 1975. Cold War History, 9, 1-22. Available at: https://doi.org/10.1080/ 14682740802490380.

Deletant, D. (2008). Romania's return to Europe. Between politics and culture. In R. Detrez and B. Segaert (eds.). Europe and the historical legacies in the Balkans (pp. 83-98). Brussels: Peter Lang.

Dimitrakopoulos, D. (2010). Introduction. Social-democracy, European integration and preference formation. En D. Dimitrakopoulos (ed.). Social Democracy and European Integration: The politics of preference formation. Abingdon: Routledge. Available at: https://doi.org/10.4324/9780203845349.

Dragomir, E. (2012). The perceived threat of hegemonism in Romania during the second détente. Cold War History, 12, 111-134. Available at: https://doi.org/10.1080/1468274 5.2010.510837.

- (2014). Cold War Perceptions. Romania's policy change towards the Soviet Union, 19601964. Helsinki: Helsinki University Printing House.

Fry, J. (1993). The Helsinki Process: Negotiating Security and Cooperation in Europe. Washington DC: National Defense University Press. Available at: https://doi.org/10.21236/ ADA276654.

González Aldea, P. (2008). Helsinki 1975. Inceputul sfârșitului. București: Curtea Veche.

Ham, P. van (1995). The EC, Eastern Europe and European Unity: Discord, Collaboration and Integration Since 1947. London: Pinter.

Hanhimäki, J. (2003). "They can write it in Swahili": Kissinger, the Soviets, and the Helsinki accords, 1973-75. Journal of Transatlantic Studies, 1, 37-58. Available at: https://doi. org/10.1080/14794010308656791.

- (2010). Détente in Europe, 1962-1975. En M. Leffler and O. A. Westad (eds.). Cambridge History of the Cold War, vol. II. Cambridge: Cambridge University Press. Available at: https://doi.org/10.1017/CHOL9780521837200.011.

Heraclides, A. (2014). Security and Co-operation in Europe: The Human Dimension 19721992. Abingdon: Routledge. Available at: https://doi.org/10.4324/9781315035840.

Jarzabek, W. (2008). Hope and Reality: Poland and the Conference on Security and Cooperation in Europe, 1964-1989. Working Paper, 65. Washington DC: Woodrow Wilson International Center for Scholars. 
Ludlow, P. (2010). European integration and the Cold War. In M. Leffler and O. A. Westad (eds.). Cambridge History of the Cold War, vol. II. Cambridge: Cambridge University Press. Available at: https://doi.org/10.1017/CHOL9780521837200.010.

Miklóssy, K. (2011). Khrushchevism after Khrushchev: the rise of national interest in the Soviet bloc. In J. Smith and M. Ilic (eds.). Khrushchev in the Kremlin: Policy and Government in the Soviet Union, 1953-64 (pp. 150-170). Abingdon: Routledge.

Morgan, M. C. (2020). The Final Act: The Helsinki Accords and the Transformation of the Cold War. Princeton: Princeton University Press.

Pechlivanis, P. (2017). Between Détente and Differentiation: Nixon's visit to Bucharest in August 1969. Cold War History, 17, 241-258. Available at: https://doi.org/10.1080/146 82745.2016.1267144.

Petrescu, D. (2009). Building the nation, instrumentalizing nationalism: revisiting Romanian National Communism, 1956-1989. Nationalities Papers, 37, 523-544. Available at: https://doi.org/10.1080/00905990902985728.

Radchenko, S. (2009). Two Suns in the Heavens: The Sino-Soviet Struggle for Supremacy, 1962-1967. Washington DC: Woodrow Wilson Center Press. Available at: https://oi. org/10.4000/chinaperspectives.4954.

Rey, M. P. (2008). The USSR and the Helsinki process, 1969-1975: optimism, doubt or defiance? In A. Wenger, V. Mastny and C. Nuenlist (eds.). Origins of the European Security System: The Helsinki Process Revisited, $1965-75$ (pp. 65-82). Abingdon: Routledge. Available at: https://doi.org/10.4324/9780203895306.ch4.

Romano, A. (2009). From Détente in Europe to European Détente: How the West Shaped the Helsinki CSCE. Brussels: Peter Lang.

Sarotte, M. E. (2008). The Frailties of Grand Strategies: A Comparison of Détente and Ostpolitik. In F. Logevall and A. Preston (eds.). Nixon in the World. American Foreign Relations, 1969-1977 (pp. 146-163). Oxford: Oxford University Press.

Soutou, G. H. (2007). The linkage between European integration and detente. The contrasting approaches of de Gaulle and Pompidou, 1965-1974. In P. Ludlow (ed.). European Integration and the Cold War: Ostpolitik-Westpolitik, 1965-1973 (pp. 11-35). Abingdon: Routledge. Available at: https://doi.org/10.4324/9780203088975.ch1.

Stanciu, C. (2013). Crisis management in the Communist bloc: Romania's policy towards the USSR in the aftermath of the Prague Spring. Cold War History, 13, 353-372. Available at: https://doi.org/10.1080/14682745.2012.746955.

(2015). Nicolae Ceauşescu and the origins of Eurocommunism. Communist and Post-Communist Studies, 48, 83-95. Available at: https://doi.org/10.1016/j.postcomstud.2015.01.006.

Tismăneanu, V. (1991). Reinventing Politics. Eastern Europe from Stalin to Havel. New York NY: Free Press.

- (2003). Stalinism for All Seasons: A Political History of Romanian Communism. Berkeley CA: University of California Press.

Watts, L. (2012). A Romanian INTERKIT? Soviet Active Measures and the Warsaw Pact "Maverick" 1965-1989. Working Paper, 65. Washington DC: Woodrow Wilson International Center for Scholars. 
Wenger, A. (2004). Crisis and Opportunity: NATO's Transformation and the Multilateralization of Détente, 1966-1968. Journal of Cold War Studies, 6, 22-74. Available at: https://doi.org/10.1162/152039704772741588.

— and Mastny, V. (2008). New perspectives on the origins of the CSCE process. In A. Wenger, V. Mastny and C. Nuenlist. Origins of the European Security System: The Helsinki Process Revisited, 1965-75 (pp. 3-20). Abingdon: Routledge. Available at: https://doi.org/10.4324/9780203895306.ch1.

Zagorski, A. (2018). The Human Dimension of the CSCE, 1975-1990. In N. Badalassi and S. Snyder (eds.). The CSCE and the End of the Cold War: Diplomacy, Societies and Human Rights, 1972-1990 (p. 17). New York; Oxford: Berghahn Books. Available at: https://doi.org/10.2307/j.ctvw049dp.7.

\section{ACRONYMS}

ANR: Arhivele Naționale ale României [National Archives of Romania]

CC: Comitetul Central [Central Committee]

CMEA: Council for Mutual Economic Assistance

CSCE: Conference on Security and Co-operation in Europe

EEC: European Economic Community

MFA: Ministry of Foreign Affairs

NATO: North Atlantic Treaty Organization

PCR: Partidul Comunist Român [Romanian Communist Party]

SALT: Strategic Arms Limitation Talks

UN: United Nations

USSR: Union of Soviet Socialist Republics 